\title{
IMPROVING OPEN INNOVATION: CHALLENGES FOR MANAging COMMUNiCATION AND Creative IdeATion
}

\author{
VRGOVIC, P.; Walton, A. \& SHUlKin, R.
}

Abstract: In recent years, Open Innovation is a paradigm that challenges almost every company that tries to innovate. There are few companies that can innovate on their own; all that can't are often advised to turn to external sources of good ideas. This strategy requires good connections with the external collaborators, in order to innovate on what others have ideated. Among others, communication is a set of tools that are necessary for successful company improvements. In this paper we try to discover relationship between ideation and communication, in the context of open innovation.

Key words: open innovation, creativity, ideation, communication
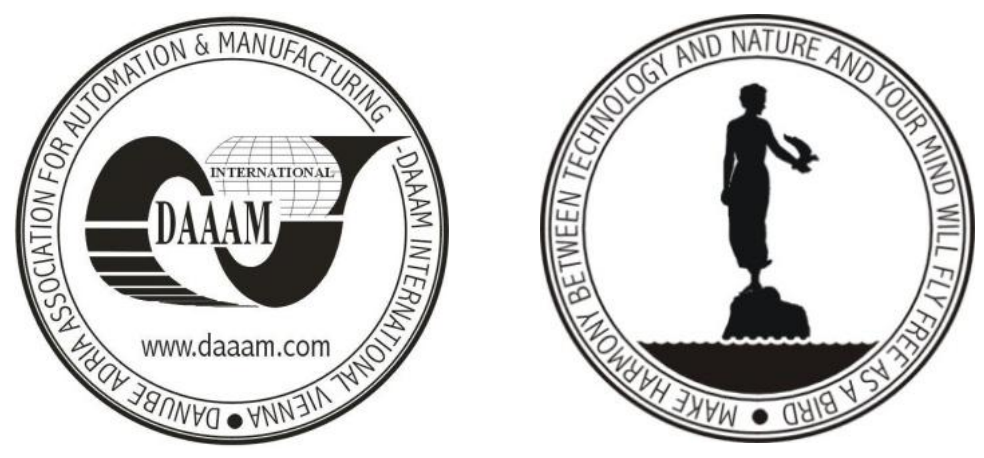

Authors' data: Assistant professor, Dr. Vrgovic, P[etar]*; Associate Professor, Dr. Walton, A[bram $]^{* *}$; Shulkin, R[on]***,* Faculty of Technical Sciences, University of Novi Sad, Trg Dositeja Obradovica 7, 21000 Novi Sad, Serbia, ** Florida Institute of Technology; Melbourne, FL 32901, USA, ***CogniStreamer, Inc.; 740 Wildwood, Mundelein, IL 60060, USA, vrgovic@uns.ac.rs, awalton@fit.edu, ron@shulkin.net

This Publication has to be referred as: Vrgovic, P[etar], Walton, A[bram] \& Shulkin, R[on] (2013) Improving Open Innovation: Challenges for Managing Communication and Creative Ideation, Chapter 57 in DAAAM International Scientific Book 2013, pp. 921-940, B. Katalinic \& Z. Tekic (Eds.), Published by DAAAM International, ISBN 978-3-901509-94-0, ISSN 1726-9687, Vienna, Austria DOI: $10.2507 /$ daaam.scibook.2013.57 
Vrgovic, P.; Walton, A. \& Shulkin, R.: Improving Open Innovation: Challenges for...

\section{Introduction}

Open innovation is one of the most frequently discussed terms in scientific management literature during the last decade. Being a relatively novel term, it's meaning, importance, and application are often misunderstood and interpreted differently across industries. Chesbrough's original opinion that "Firms can and should use external ideas as well as internal ideas, and internal and external paths to the market, as the firms look to advance their technology" (Chesbrough, 2003, p. xxiv) has been interpreted in many ways, resulting in corporations developing overly closed approaches as well as unnecessarily open approaches to innovation. While the field of open and disruptive innovation brings many new opportunities and methods to innovate, it also incites new debates and discussions in the scientific fields. The main concept lies in acquiring knowledge from external sources; which, implies that some of the main concerns both scholars and practitioners face are the role and the importance of the various sources of ideas for innovation; knowing how to collect, catalogue, sift through, and identify potentially fruitful ideas that a company can then implement or produce. These concerns are always multidimensional, and require a complex set of skills in order to manage effectively; it is not unlikely that corporations may hire more than one person to achieve their goals from these endeavours, and they therefore create teams with different competencies in order to harness creative potentials. The overly-open innovation models present the risk of further exacerbating resource demand due to the excessively large number of ideas from their myriad contributors. Furthermore, since many companies also practice outbound open innovation, opening up their innovation process to knowledge exploitation by the market and other companies, it is important to appropriately design communication practices in order to recycle previous innovation and/or idea campaign results. Lastly, combining outside-in and inside-out processes requires integration of inbound and outbound open innovation (Gassmann, Enkel, \& Chesbrough, 2010).

Thus, by following the proposed chapter structure this paper aims to systematically identify and explicate the communication practices and creative outcomes of companies that regularly strive to innovate: firstly, previous research and theory will be summarized to depict the current state of knowledge in this field; secondly, known issues related to open innovation research will be analysed; thirdly, new trends that are changing the emerging paths of research will be described; and lastly, future challenges will be identified, while proposing several directions for engineering managers to pursue in their open innovation endeavours.

\section{Current State of Knowledge}

In the field of collaborative, distributed innovation, there are two main streams that shape what we know and use today. Von Hippel's research have established the importance of user innovation (Von Hippel, 1978), while also addressing the 
importance of innovation dissemination. This stream of literature emphasizes users' creative potentials that are used by the company to design new products: in order to achieve this, the company must actively communicate with its users, gathering everything from concepts, through elaborated ideas and product designs, to working prototypes. On the other end of the spectrum, Chesbrough's (2003) open innovation approach (using the term 'open innovation' in its more narrow meaning) relates to companies co-operating across firm boundaries in order to create and commercialize innovations. This stream of literature emphasizes the connections between different companies, emphasizing high degrees of trust and quality communication in order to share innovations with others. These two streams theoretically cover a major portion of the open innovation literature, with a large number of scientific papers published, showing that a company can utilize both the users and the competition to develop its own innovation pipeline in addition to helping others or their industry at-large. Lately, additional approaches have further diversified this field of research by focusing on some other aspects of innovation: cumulative innovation, where sharing/shared conditions are emphasized by attending to the legal and social contexts(Murray \& O'Mahony, 2007);open community innovation, where the focus is on a type of organized and independent association of actors (i.e., agents)(West \& Lakhani, 2008; West \& O'mahony, 2008)or social production and co-creation, with social aspects as the main focus(Benkler, 2006; Bogers, Afuah \& Bastian, 2010). All of these perspectives on open, distributed innovation concentrate on different aspects and, although they can sometimes be complementing, they often offer conflicting predictions for some phenomena and congruent predictions for others (Bogers \& West, 2012). Therefore, managerial practice should carefully define what type of innovation it requires in order to fully utilize the selected approach; while some companies actively solicit innovations from external subjects by using available toolkits, campaigns or platforms, other companies strive to identify and capture the personal value created a priori by external subjects.

Since this chapter primarily observes idea stimulation, idea creation and idea sharing/capturing as steps in the companies' innovation efforts, it is evident that both the personal and the organizational factors should be addressed. Since interests of the external stakeholders and the focal company can often be misaligned (West \& Gallagher, 2006), it is a big challenge to properly engage, motivate, and steer the stakeholders to give inputs that create value for the company and meets its innovation needs. Companies have both the pecuniary and non-pecuniary methods to motivate external stakeholders, such as profit sharing, fixed-amount prizes, stock sharing, special discounts or offers. Non-pecuniary methods may include direct and indirect benefits of sharing knowledge with the community, and providing ideas that will result in a product or service that meets users' own needs(Von Hippel, 2007).

There is also a good number of techniques to stimulate useful ideas, including those that employ the individual, group or hybrid approaches. Various studies have shown that ideation stimulation might be achieved by verbal or other cognitive stimuli (Knoll \& Horton, 2011; Liikkanen \& Perttula, 2010; Misawa \& Fujita, 2009), 
Vrgovic, P.; Walton, A. \& Shulkin, R.: Improving Open Innovation: Challenges for...

by ideas of others (Leggett Dugosh et al., 2000; Nijstad, Stroebe, \& Lodewijkx, 2002), by cognitive training (Dahl \& Moreau, 2002; Iyer et al., 2009; Marakas \& Elam, 1997), or even using special software (MacCrimmon \& Wagner, 1994; Rangaswamy \& Lilien, 1997; Verhaegen et al., 2011). We also know that some sorts of hybrid ideation bring superior results, being able to use collaborative and stimulating synergies, while eliminating the frequent pitfalls of the classic groupideation techniques, such as free-riding or production-blocking(Aiken, Sloan, Paolillo, \& Motiwalla, 1997; Diehl \& Stroebe, 1987). Finally, recent research has shown that social aspects have a crucial role in good ideation results, advocating for communication with people with diverse interests or knowledge (Björk, 2012; Gemmell, Boland, \& Kolb, 2012; Sosa, 2011).

Currently, there are myriad methods for capturing the creative potential of internal and external stakeholders, employees, partners, and clients. In order to yield positive innovation results, communication between a corporate champion and the lead ideator needs to be carefully designed to allow for a win-win outcome. A large number of tools specially designed for a company's intranet or the internet are available to organize, incentivize, collect, and manage ideas needed for corporate innovation. These tools have different success rates in achieving the goals that were set, which is most often moderated by a company's innovation approach and policy, rather than the tool efficacy itself. Often, the management of these innovative efforts by the company is complex, a recent study (Mendonca, Povoa, \& Oliveira, 2012) has shown that best Idea Management practices can be conceptualized by four dimensions, using both internal and external creative sources: collaborative work environment, employees' participation, communication networks and external sources of ideas; furthermore, it was shown that these organizational routines have an impact on the propensity to develop innovative products and services and enhance the existing ones.

It is evident that all of these complex processes ask for some sort of formalized management system, in order to have expected results, usually via some sort of idea management system. The problem that is present here is how to capture various ideas submitted by the employees and the public? One recent theoretical model (Sandström \& Björk, 2010) proposes a dual idea management system that is able to deal with both continuous and discontinuous innovation, regardless of the idea source. By making a distinction between two types of ideas, treating them with different processes and evaluation criteria, this dual system might be able to utilize a wide array of submitted ideas. This is an important point of discussion, because as other recent additions to literature have shown, institutional processes and requirementsbased engineering does not yield innovation, but prescriptive outcomes that yield incremental improvements at best (Grieves, 2014).

However, capturing creative ideas is often not enough to innovate on them as they can be underdeveloped, so they need some kind of elaboration (validation and augmenting) to develop the concept; successful elaboration of an idea by the creator and a company partner requires a specific fit of complementary skills from both 
sides, so the elaboration is sometimes delegated to some sort of public forum or community. One theoretical model (Hellmann \& Perotti, 2011) stresses the importance of free idea circulation, predicting a symbiotic relationship between firms and markets based on rich communication channels necessary to develop ideas. Nonetheless, any resulting idea that is subsequently selected for development and is thusly pushed into the new product pipeline requires specific and systematic idea evaluation and evidence gathering processes be completed; should sufficient evidence fail to be gathered, the idea will likely be cut at subsequent stage gates or reviews (Glassman \& Walton, 2014). The development of key performance indicators and metrics should therefore be completed prior to any open innovation initiative, with an eye towards key metrics that would come into play over the product's entire lifecycle (Walton, Tomovic, \& Grieves, 2013).

\section{Conceptual and Methodological Issues}

Little, if any, scientific advancement can be gained without a common core set of well-defined terminology related to a field of inquiry. This is true not only in science and engineering, but in any field of study where thought leaders desire to have an impact in their field via meaningful contributions. Unfortunately, if terminology is not well defined, then contributions may not convey the appropriate meaning, and thus lose their potential impact. Thus, while key innovation terms are widely used, they are frequently misunderstood or used with different intended meanings. As mentioned in the previous section, the basic concept of open innovation has more than one interpretation: Dahlander and Gann (2010), after reviewing 150 open innovation papers, conclude that researchers tend to use different definitions, and also to focus on different aspects in this field. Resultantly, the methods for consistently measuring the outcomes and efficacy of innovation efforts (especially open innovation) are still up for debate and lacking in consensus among innovation thought leaders. Moreover, other additional aspects are also hard to reliably assess: motivation and readiness to share ideas, idea conversion, idea quality, fuzzy front end properties, key performance indicators, and product lifecycle management metrics, etc.

For example, motivation for idea creation and idea sharing is a complex phenomenon that we are yet to fully understand. There is a significant lack of theory and theoretical perspectives from which the 'user-innovation literature' draws, especially in the management literature (Bogers et al., 2010): proposed explanations such as expected benefits, information stickiness, intrinsic benefits, career concerns or user's knowledge and expertise fail to add up to a coherent theoretical explanation. Some anecdotal research results concentrate on internal, subjective motivators (Daniels et al., 2011; Jung, Lee, \& Karsten, 2011; Obschonka, Silbereisen, \& Schmitt-Rodermund, 2012), while others may point to external, financial factors (Toubia, 2006); some research even suggest that creative thinking can and should be 
Vrgovic, P.; Walton, A. \& Shulkin, R.: Improving Open Innovation: Challenges for...

taught, and reinforced through positive feedback channels, rather than just motivated (Daley, 2005).

Companies often report that they communicate only with limited number of external subjects when searching for creative ideas. Regarding the end users, companies may face different types of consumers that are able to ideate: average consumers that are high in numbers and tend to use products and services with their basic functions; technical experts (lead users) that are for some reason very informed about the underlying product technology and tend to use more product features, even customizing some of them; creative consumers that may not possess the advanced knowledge about the product's underlying technology, but still tend to think of new uses or extensions for it. Berthon (Berthon et al., 2007, p. 41) described a "creative consumer" as an idea source that is different than a "lead user": a creative consumer works with all types of offerings, not just with novel or enhanced products; he sometimes faces needs that will not become general; he will often only indirectly or symbolically benefit from his innovation; companies do not find, screen and select him through a formal process. This means that there is a big potential for creative ideas from ordinary users, which is untapped if a company seeks only advanced users, or if it passively receives ideas that highly proactive users want to share. Distinction between regular users, lead users and creative users is very important when deciding who to motivate for ideation, and how to deal with their continued interaction (Berthon et al., 2007). Some types of innovation efforts may be undermined by consumers' inputs, because they tend to have "a very limited frame of reference" (Ulwick, 2002, p. 92); in that case, it is advised that the company should ask for their desired outcomes, rather than users' suggestions and ideas for innovations. Some companies might take the opposite approach, to extremely include their customers in the innovation process, asking them to steer the product development vianear-constant market probing (Gassmann, Sandmeier, \& Wecht, 2006). This is also dependent on the type of customers the company is seeking: it is recorded that an average customer tends to generate incremental ideas, while lead users tend to create more novel and radical ideas (Lilien, Morrison, Searls, Sonnack, \& Hippel, 2002).

Stimulating creative thinking and ideation has problems of its own. Since idea generation is basically a creative process based on individual capabilities, or at best, synergistic outcomes that are nearly impossible to predict (e.g., the unknown and intangible benefits of including a diverse set of ideators in a particular campaign e.g., an anthropologist working on a new toothbrush idea), companies and scholars often believe that the management should not interact directly in any way (Sowrey, 1990), limiting themselves only to setting the necessary conditions and stimulating contexts for ideation to take place. Indeed, there are numerous research papers that neglect the ideation stimulation: when researching idea management as a part of innovation activities, it is not uncommon to neglect the importance of controlled ideation, although it is perceived as a critical part of the innovation process (Cooper, 2008): it is implicitly assumed that ideas are spontaneously and uncontrollably 
created and that it is company's task to collect them or find them in the most efficient and efficacious manner possible(Brem \& Voigt, 2007; Cooper, 2008; Thom \& Etienne, 2000). Similarly, Bessant et al. (2005) further refines the concept of "managing the idea generation process" by discussing the need to, "enable systematic and high involvement in innovation", thusly ignoring the stimulation step. Furthermore, in a review of open innovation papers, West and Bogers (West \& Bogers, 2011, p. 8) parse the step of "obtaining external innovations" into several steps, where "enabling" and "incentivizing" are limited only to motivational rewards and innovation contests, without stimulating ideation directly. In contrast to this, there is numerous evidence that companies can successfully stimulate ideation in multiple methods. The way companies describe or present their problems, and the context in which the problem is being solved can be a stimulation in its own regard (Magnusson, 2009; Piller \& Walcher, 2006), for instance, social stimuli may improve customer ideation (Alam, 2003; Chalkiti \& Sigala, 2008), while external stimuli may also help in idea creation (Dodds, Smith, \& Ward, 2002; Knoll \& Horton, 2011; Rangaswamy \& Lilien, 1997).

The measurement of and methods for measuring inputs and outputs of distributed innovation are also widely debated. It is an open question as whether to observe idea quantity (Stevens \& Burley, 1997), idea quality (Girotra, Terwiesch, \& Ulrich, 2010), failure rate of the invention-innovation path(Kusiak, 2009), adoption of innovation culture within the company (Balsano et al., 2008; Chiaroni, Chiesa, \& Frattini, 2010) or even the ability to create and maintain a sponsored open source community (West \& O'mahony, 2008). Since innovation is a complex phenomenon, this question probably cannot be easily modelled and answered uniformly. Companies around the world have different contexts in which they operate, differentiation strategies them employ, and therefore a unique balance of many factors should be made for innovation to take its proper course. Ideation metrics are complex in and of themselves; Shah (Shah, Smith, \& Vargas-Hernandez, 2003) proposes quantity, quality, novelty and variety; Nelson (Nelson, Wilson, Rosen, \& Yen, 2009) calculates a single metric that combines novelty and variety; some believe that idea quantity eventually results in idea quality (Baruah \& Paulus, 2008; Karni \& Shalev, 2004), while others state the relationships are complex or not of big impact (MacCrimmon \& Wagner, 1994; Rietzschel, Nijstad, \& Stroebe, 2006). Additionally, perspectives differ when observing the idea screening steps: we do not have an uniform answer regarding the questions "who should assess the submitted ideas?" (Glassman \& Walton, 2014); "are internal managers most capable of that?" (Schulze, Indulska, Geiger, \& Korthaus, 2012), or "should other stakeholders be involved, including previous consumers" (Toubia \& Florès, 2007)? And, for each reviewer, which evidence is most suitable for consideration (Glassman \& Walton, 2014)?

As a function of overall methodology then, companies who engage in purposeful innovation programs must consider the methods by which they plan to thoroughly and appropriately gather evidence for/against certain types of ideas, and how best to ensure the depth, breadth, and variety of desired ideas appropriately enter the full 
development pipeline. A short discussion is thusly warranted on the cautions and best practices of evidentiary and evaluative processes for innovation programs; such practices are even more vital for open innovation programs, where the diversity and plethora of ideas might often expectantly exceed the capacity of reviewers or gatekeepers to effectively review ideas. This section on idea evaluation is not meant to serve as an exhaustive review of the literature or set of best practices, but to shed light on commonly overlooked steps in the process; see for a further discussion of these points.

Ideas entering an open innovation pipeline, whether from a digital front end, or via a multitude of other methods, e.g., focus groups, interviews, observations, drop boxes, competitions, etc., eventually need to be screened. A first screen should be setup, which has an entirely different set of guidelines, criteria, methods, and intended outcomes than mid or final screens.

\begin{tabular}{|l|l|l|l|}
\hline Source & Largest Benefit & Largest Limitation & Largest Cost Dependency \\
\hline Interviews & Deep questioning & Not easily scaled & Hourly costs \\
\hline Online surveys & Deep questioning & Not easily scaled & Participant compensation \\
\hline Hand-out surveys & Large sample size & Limited distribution & Cost to distribute \\
\hline Online Polls & Large sample size & Limited information & Cost to distribute \\
\hline In-person Polls & Broad sample & Limited to locations & Cost to distribute \\
\hline Focus groups & Deep questioning & $\begin{array}{l}\text { Limited by number } \\
\text { of moderators }\end{array}$ & Participant compensation \\
\hline Group conversations & Deep questioning & $\begin{array}{l}\text { Limited by number } \\
\text { of moderators }\end{array}$ & Participant compensation \\
\hline Email questioning & Large sample size & Limited information & $\begin{array}{l}\text { Hourly cost required to } \\
\text { respond and analyze }\end{array}$ \\
\hline Phone interviews & Deep questioning & Not scalable & Interviewer compensation \\
\hline Web Conferencing & Deep questioning & $\begin{array}{l}\text { Limited by number } \\
\text { of moderators }\end{array}$ & Moderator compensation \\
\hline Online Polls & Large sample size & Limited information & Cost to distribute \\
\hline Interactive tours & Deep questioning & Not easily scaled & Participant compensation \\
\hline $\begin{array}{l}\text { In-person } \\
\text { Competitions }\end{array}$ & Deep questioning & Not easily scaled & Participant compensation \\
\hline Online Competitions & Large sample size & Building awareness & Participant compensation \\
\hline
\end{tabular}

Tab. 1. Methods for gathering evidence from primary sources

Given that initial ideas submitted may be very loosely defined or poorly developed, if too stringent of criteria are set for a first screen, what would otherwise potentially be a valuable, disruptive idea, might be unintentionally screened out of the process. Metrics should therefore be setup prior to an initial screen to require 
reviewers to evaluate ideas against a baseline set of criteria. These criteria should be developed interdisciplinarily across business units/functions, and then summarily distributed back across the same organization for agreement and adherence. Once criteria are set, predetermined methods of gathering evidence should commence. The tables $1 \mathrm{a}$ and $1 \mathrm{~b}$ is list of primary methods for evidence gathering and their appropriate outcomes (Glassman \& Walton, 2014).

\begin{tabular}{|c|c|c|c|}
\hline Source & Largest Benefit & Largest limitation & Largest Cost Dependency \\
\hline $\begin{array}{l}\text { Employee web } \\
\text { access }\end{array}$ & $\begin{array}{l}\text { Free sources of } \\
\text { information }\end{array}$ & $\begin{array}{l}\text { Screening out less } \\
\text { valuable } \\
\text { information }\end{array}$ & Employee hourly costs \\
\hline Library access & $\begin{array}{l}\text { Massive stores of } \\
\text { knowledge }\end{array}$ & $\begin{array}{l}\text { Their archive and } \\
\text { online access }\end{array}$ & Subscription costs \\
\hline $\begin{array}{l}\text { Paid consultant } \\
\text { /contractor }\end{array}$ & $\begin{array}{l}\text { Experts knows info or } \\
\text { has access to key } \\
\text { sources }\end{array}$ & $\begin{array}{l}\text { Their expertise } \\
\text { areas }\end{array}$ & Consulting hourly costs \\
\hline $\begin{array}{l}\text { Automatic Alerts } \\
\text { (Google Alerts) }\end{array}$ & $\begin{array}{l}\text { Up-to-date news and } \\
\text { information }\end{array}$ & $\begin{array}{l}\text { Unscreened } \\
\text { information }\end{array}$ & Employee hourly costs \\
\hline $\begin{array}{l}\text { Paid databases } \\
\text { (Scopus.com) }\end{array}$ & $\begin{array}{l}\text { Accurate up-to-date } \\
\text { statistics }\end{array}$ & $\begin{array}{l}\text { Range of statistics } \\
\text { and info }\end{array}$ & Subscription costs \\
\hline Academic journals & $\begin{array}{l}\text { Expert accurate } \\
\text { knowledge }\end{array}$ & Range of topics & Subscription costs \\
\hline Trade journals & $\begin{array}{l}\text { Expert accurate } \\
\text { knowledge }\end{array}$ & Range of topics & Subscription costs \\
\hline $\begin{array}{l}\text { Published } \\
\text { Magazines }\end{array}$ & $\begin{array}{l}\text { Quickly digestible } \\
\text { info }\end{array}$ & $\begin{array}{l}\text { Limited depth of } \\
\text { info }\end{array}$ & Subscription costs \\
\hline Search engines & Large range of info & $\begin{array}{l}\text { Screening out low } \\
\text { quality info }\end{array}$ & Employee hourly costs \\
\hline Online dictionaries & Large range of topics & Out-of-date info & Employee hourly costs \\
\hline $\begin{array}{l}\text { Professional } \\
\text { organization }\end{array}$ & Focused topics & Limited focus & Membership costs \\
\hline Patent databases & Easy to find info & Limited to patented & Employee hourly costs \\
\hline $\begin{array}{l}\text { Marketing/industry } \\
\text { research reports }\end{array}$ & $\begin{array}{l}\text { Quickly digestible } \\
\text { info }\end{array}$ & $\begin{array}{l}\text { Limitation of the } \\
\text { study }\end{array}$ & Costs per report \\
\hline $\begin{array}{l}\text { Paid marketing } \\
\text { research }\end{array}$ & $\begin{array}{l}\text { Quickly digestible } \\
\text { info }\end{array}$ & Research budget & Consulting costs \\
\hline Published books & Depth of information & Focused topic & Employee cost to read \\
\hline $\begin{array}{l}\text { Government } \\
\text { (census) }\end{array}$ & Depth of information & $\begin{array}{l}\text { Un-analyzed } \\
\text { information }\end{array}$ & Employee cost to read \\
\hline Social media sites & Large sample size & $\begin{array}{l}\text { Lots of false } \\
\text { information }\end{array}$ & Employee cost to read \\
\hline $\begin{array}{l}\text { Online websites } \\
\text { (Amazon, } \\
\text { competitor home } \\
\text { page) }\end{array}$ & Large range of topics & $\begin{array}{l}\text { Lots of false } \\
\text { information }\end{array}$ & Employee cost to read \\
\hline
\end{tabular}

Tab. 2. Methods for gathering evidence from secondary sources 
Vrgovic, P.; Walton, A. \& Shulkin, R.: Improving Open Innovation: Challenges for...

\begin{tabular}{|c|c|c|}
\hline & Definition & Acceptability for a first screen? \\
\hline $\begin{array}{l}\text { Theme } \\
\text { Criteria }\end{array}$ & $\begin{array}{l}\text { Multiple themes are created, if an idea } \\
\text { fits into those predetermined themes } \\
\text { then it is accepted (ex. operational } \\
\text { improvements, branding } \\
\text { improvements, revolutionary } \\
\text { products). } \\
\text { Used when an organization wants to } \\
\text { focus on a few core areas. } \\
\text { Downside is if the themes are too } \\
\text { broad or too narrow then all ideas or } \\
\text { too few ideas will be accepted. } \\
\text { Themes have to be updated every few } \\
\text { months to align with strategic goals. }\end{array}$ & $\begin{array}{l}\text { YES } \\
\text { This is the most acceptable first screen } \\
\text { because employees can self-check if their } \\
\text { idea fits a pre-determined theme. Further, } \\
\text { it forces employees to find ideas that fit } \\
\text { those themes. Finally it is fair, if an idea } \\
\text { matches a theme then it is accepted into } \\
\text { evaluation. }\end{array}$ \\
\hline $\begin{array}{l}\text { Exclusion } \\
\text { or } \\
\text { Inclusionar } \\
\text { y Criteria }\end{array}$ & $\begin{array}{l}\text { Multiple inclusion criteria (10 or } \\
\text { more) should be set. These are general } \\
\text { criteria, such as, does it help expand } \\
\text { the brand, improve customer } \\
\text { relationships, etc... } \\
\text { Exclusion criteria should be set } \\
\text { carefully and only really be around the } \\
\text { values of the company. Ex. Does the } \\
\text { idea violate "being honest with the } \\
\text { customer" }\end{array}$ & $\begin{array}{l}\text { YES } \\
\text { Inclusion criteria for a screen are } \\
\text { preferable, does the idea help increase } \\
\text { operational efficiency? If yes then } \\
\text { keeping inclusion criteria broad around } \\
\text { certain themes is helpful. } \\
\text { Exclusion criteria must be set carefully as } \\
\text { it is too easy to create a situation where } \\
\text { few ideas are eligible to be included. }\end{array}$ \\
\hline $\begin{array}{l}\text { Grouping } \\
\text { or Tiers }\end{array}$ & $\begin{array}{l}\text { Much like themes that categorize ideas } \\
\text { based on similarities, groups can be } \\
\text { helpful in evaluation as the methods } \\
\text { used to evaluate them are similar. } \\
\text { Tiers like top ideas, or worst ideas } \\
\text { related to operational improvements } \\
\text { can be used very effectively as a first } \\
\text { screen. } \\
\text { However, both grouping and tiers can } \\
\text { only be used in a batch evaluation } \\
\text { process, not a continuous process. }\end{array}$ & $\begin{array}{l}\text { YES } \\
\text { Evaluating a group of similar ideas is } \\
\text { much easier than dissimilar ideas. } \\
\text { Evaluating top tier ideas in a particular } \\
\text { theme helps maximize and focus scarce } \\
\text { resources. }\end{array}$ \\
\hline $\begin{array}{l}\text { Idea } \\
\text { Sponsor }\end{array}$ & $\begin{array}{l}\text { A member of the selection committee } \\
\text { can decide to sponsor an idea. The } \\
\text { number of ideas they can sponsor can } \\
\text { be limited based on fairness or } \\
\text { resource limitation. This allows } \\
\text { executives to push ideas they see } \\
\text { valuable though the corporation. } \\
\end{array}$ & $\begin{array}{l}\text { YES } \\
\text { If the idea has a department head that is } \\
\text { sponsoring it than it will receive the } \\
\text { needed resource in the following phases } \\
\text { of gathering evidence and analysis. } \\
\text { Sponsored ideas are an old method of } \\
\text { bringing ideas to fruition. }\end{array}$ \\
\hline $\begin{array}{l}\text { Checklist } \\
\text { or } \\
\text { Threshold }\end{array}$ & $\begin{array}{l}\text { An individual idea's list of attributes } \\
\text { must match the checklist or threshold } \\
\text { in order to pass (for example be } \\
\text { implemented in } 6 \text { months, profit at } \\
\text { least } \$ 500,000, \text { and require no more } \\
\text { than two employees) }\end{array}$ & $\begin{array}{l}\text { NO } \\
\text { It is too easy to poorly choose an attribute } \\
\text { and create a barrier to early stage ideas, } \\
\text { especially where solutions to problems } \\
\text { with the idea have not been derived. }\end{array}$ \\
\hline
\end{tabular}

Tab. 3. Screening methods and their acceptability for use during the first screen 


\begin{tabular}{|c|c|c|}
\hline & Definition & Acceptability for a first screen? \\
\hline $\begin{array}{l}\text { Personal } \\
\text { preference }\end{array}$ & $\begin{array}{l}\text { A manager, director, line-employee, or } \\
\text { even expert is used to screen an idea } \\
\text { based on his or her own preferences. }\end{array}$ & $\begin{array}{l}\text { NO } \\
\text { This should not be used as it is highly } \\
\text { biased and viewed as unfair for any type } \\
\text { of screen. } \\
\text { Experts are often called in to perform a } \\
\text { first screen, this can be helpful if the idea } \\
\text { is accepted, but due to their depth of } \\
\text { knowledge they almost always tend to } \\
\text { evaluate the idea more fully, finding } \\
\text { immediate holes and issue which should } \\
\text { only be address in the later stages of } \\
\text { evaluation. }\end{array}$ \\
\hline Voting & $\begin{array}{l}\text { An individual can vote openly or in a } \\
\text { closed ballot i.e. blind / peer review. } \\
\text { Voting can be weighted; an individual } \\
\text { can give multiple votes to a given } \\
\text { idea, for example an expert in a } \\
\text { technology area could be given } 20 \\
\text { votes compared to a non-expert's } 1 \\
\text { vote. }\end{array}$ & $\begin{array}{l}\text { NO } \\
\text { Voting to pass an idea into evaluation } \\
\text { will seem unfair to the idea submitter } \\
\text { Personal preference and politics play a } \\
\text { large role, see reasons for rejecting that } \\
\text { screening method above. } \\
\text { More importantly, it is difficult to predict } \\
\text { if an idea will pass a first screen and thus } \\
\text { it may prevent employees from } \\
\text { submitting ideas }\end{array}$ \\
\hline $\begin{array}{l}\text { Point } \\
\text { scoring }\end{array}$ & $\begin{array}{l}\text { An individual uses a scoring sheet to } \\
\text { rate a particular idea on its attributes } \\
\text { (e.g., an idea that can be implemented } \\
\text { in } 6 \text { months gets }+5 \text { points, and one } \\
\text { that can make more than 'X'Dollars } \\
\text { get }+10 \text { points). } \\
\text { The points are then added together and } \\
\text { the top ideas are ranked ordered by } \\
\text { highest point scores. }\end{array}$ & $\begin{array}{l}\text { NO } \\
\text { For the same reasons as described in } \\
\text { voting }\end{array}$ \\
\hline $\begin{array}{l}\text { Rating } \\
\text { scales }\end{array}$ & $\begin{array}{l}\text { An individual rates an idea on a } \\
\text { number of preset scales (for example } \\
\text { an idea can be rated on a } 1 \text { to } 10 \text { on the } \\
\text { implement time, any idea that reaches } \\
\text { at } 9 \text { or } 10 \text { is automatically accepted) }\end{array}$ & $\begin{array}{l}\text { NO } \\
\text { For the same reasons as described in } \\
\text { voting }\end{array}$ \\
\hline $\begin{array}{l}\text { Ranking or } \\
\text { Forced } \\
\text { Ranked }\end{array}$ & $\begin{array}{l}\text { An individual must rank ideas (\#1, } 2 \text {, } \\
3, \ldots) \text { - this make the group consider } \\
\text { minor differences in idea and its } \\
\text { characteristics - for force ranking } \\
\text { there can only be one idea \#1 idea, \#2 } \\
\text { idea, so on.. }\end{array}$ & $\begin{array}{l}\text { NO } \\
\text { For the same reasons as described in } \\
\text { voting }\end{array}$ \\
\hline $\begin{array}{l}\text { Delphi } \\
\text { Method }\end{array}$ & $\begin{array}{l}\text { Creates social agreement on idea } \\
\text { selection via an iterative process } \\
\text { whereby a variety of evaluators not on } \\
\text { assess the idea, but are allowed to see } \\
\text { other evaluators opinions during their } \\
\text { review. }\end{array}$ & $\begin{array}{l}\text { NO } \\
\text { For the same reasons as described in } \\
\text { voting }\end{array}$ \\
\hline
\end{tabular}

Tab. 3. Screening methods and their acceptability for use during the first screen (cont.) 
Vrgovic, P.; Walton, A. \& Shulkin, R.: Improving Open Innovation: Challenges for...

\begin{tabular}{|l|l|l|}
\hline Resources & Definition & Acceptability for a first screen? \\
$\mathbf{E}$ & $\begin{array}{l}\text { Determine the resources or capabilities } \\
\text { Capability } \\
\text { required to develop and implement the } \\
\text { idea into the final product, service, or } \\
\text { operation. }\end{array}$ & $\begin{array}{l}\text { NO } \\
\text { As the idea has not been evaluated it is } \\
\text { not possible to accurately estimate the } \\
\text { resources and capabilities required to } \\
\text { develop it, thus one must use educated } \\
\text { guesses, which is very much open to } \\
\text { personal bias. } \\
\text { The process for evaluating ideas finds } \\
\text { solutions for acquiring resources and } \\
\text { capabilities, and thus this screen can only } \\
\text { be used as a final selection method. }\end{array}$ \\
\hline
\end{tabular}

Tab. 3. Screening methods and their acceptability for use during the first screen (cont.)

Finally, consideration should be given to the types of screens used for the initial screen vs. subsequent screens as ideas pass through the pipeline of innovation. The table 3 delineates which screening methods are appropriate, or not, given the respective screening function. One should keep in mind that, in addition to the screening methods varying from first to mid, to final, the methods of gathering evidence should also appropriately reflect and fit the screening function and type. Too loose of metrics and methods, and the result is too many and ill-defined, lowvalue producing ideas are accepted into the pipeline, thusly wasting key resources.

Alternatively, too stringent of metrics, especially for an initial screen, and the result is a small set of non-disruptive, incremental ideas that also result in low-value to the organization. Moreover, failing to setup the methods and metrics ahead of time in an interdisciplinary manner results in biased, and myopic metrics or methods that focus on sub-optimized ideas that benefit only one or two departments instead of maximizing overall corporate profits.

\section{Emerging Trends}

The open innovation paradigm has been growing a trend in the last decade, and still continues to incite new questions. Other new trends continue to shift the research and development focus: from products to services, from amateurs to professionals, from large firms to SMEs, from high-tech companies to simple products, etc.

Technology continues to support these efforts as a means to capture ideation activities, to facilitate collaboration, and to track the social networking activity as a measure of idea interest. Large organizations can fund technology to easily manage the security requirements for opening up the innovation efforts to involve external collaborators, such as customers, vendors, partners, and the public. The largest challenges with open innovation are not technology-based, but instead require companies to pre-emptively determine how to address the question of who owns the intellectual property, how will ideas be categorized, screened, and ultimately developed. Most often times, corporations employ draconian policies that require any 
idea-submitter to relinquish all rights to their idea, and while it may be true that a company is ultimately underwriting all the costs associated with research, development, and marketing, an unintended consequence of these policies is that these idea-collaborators may only submit ideas that are less plausible, or that are otherwise too expensive for smaller firms to pursue; should the latter not be true, then the idea submitter may have simply pursued the idea themself. Additionally, corporations are finding that it is no longer necessary, nor sufficient to build their own, proprietary software for idea collaboration, but instead are required to integrate their idea-generation and capture methods with social networking sites such as Yammer, Facebook, Twitter, Linkedin, etc.

Furthermore, corporations must understand and categorically predict the types and variety of responses from customers. For instance, challenges can be drawn from the general to the specific, e.g. instead of asking what suitcase ideas a customer might have, ask what colour they are willing to purchase. Every enthusiast of open innovation initially desires to solve the traffic problem in their own city, yet a more appropriate engagement of external stakeholders might be to build relationships between the various associations and their members who might otherwise not be able to collaborate, such as dairy farmers, health care professionals, and occasionally public policy specialists. In innovation circles, it is a well-known idea that industries rarely reinvent themself without the aid of an external party who has not already adopted and accepted standard industry norms. Instead, these external partners and idea-collaborators will challenge industry norms and standard practices, which ultimately yield opportunities for disruptive innovation. Oftentimes, internal stakeholders fail to understand value, because they have accepted a prior generation's value-statement. Therefore, just as technology continually enables new and innovative ways to solve a customer's need, how we define that need must also be reconsidered. Innovative companies are constantly redefining value, identifying the value stream, creating systems that flow smoothly, creating a pull-demand for their product, and pursuing perfection until the next time they make a revolutionary change, at which point, the cycle starts over. Companies that fail to understand this cycle will predictably fail to innovate consistently. Open innovation thus allows companies to iteratively revisit the market, revalidate their customers, and redefine value.

Unfortunately, another issue with collaborative, open-innovation technology systems is always ensuring ongoing adoption and engagement. Unlike more traditional enterprise-software solutions, such as those for accounts receivable or inventory management, it open innovation requires more than a top-down mandate to spur usage.

Collaborative systems must attract users and then nurture their ongoing engagement, which means companies must issue challenges via the medium(s) with which the end-user is familiar and active, such as social networks, intranets, or email. Moreover, while some idea-contributors may be drawn to submit ideas for global issues, most idea submitters are more likely to submit ideas that have an impact on 
Vrgovic, P.; Walton, A. \& Shulkin, R.: Improving Open Innovation: Challenges for...

their life, or that of their friends, or is otherwise likely to yield a significant outcome. Therefore, while companies need to understand that idea-submitters are drawn to the idea campaign due to its significant or potential impact, they are also drawn to the campaign due to the collaborative space provided via the actual mechanics of idea submission process.

\section{Future Research and Challenges}

Although still relatively new itself, research into the open innovation concept continues to uncover new issues that require attention. For instance, effective patent valuation and trading/licensing of intellectual property, the methods by which small to medium enterprises should manage open innovation, the factors of successful open innovation, the special aspects of open innovation (e.g., innovators who must work with others who are disparately located), are yet to be fully modelled.

Other issues include the gamification attributes of social networks and the resultant collaboration. For instance, if there is a prize for the best idea submitted during a 90-day challenge, users will be more likely to submit their idea(s) on day 89 for fear that others will steal or augment their idea and win the prize. This defeats the purpose of collaborative innovation. Instead users should be rewarded for their contributions as well as their ideas.

Social measurements of collaborative activity need to be included among the components of why an idea is promoted or perceived as 'best', else lobbying efforts can occur and poor ideas are artificially promoted, i.e., the best ideas should be promoted because they had the most views, follows, bookmarks, alerts, comments, votes on comments, similar ideas suggested, etc., not just the most votes.

There is software that allows such interaction, and in fact studies have shown that by engaging a multitude of collaborators, ideas are often tweaked through the submission process, whereby an idea submitter must respond to valid criticisms of an idea, ultimately resulting in a more sound and feasible idea. Through this method, not only are idea submitters rewarded, but those who also provide contributions through their feedback and efforts to build on a base idea.

Another challenge that open innovators face in the USA is the new US policy on granting patent awards, which has dramatically changed the requirements; instead of inventors having to prove 'first to invent', the new law grants priority to the inventor who is the 'first to file', which means the rapid production of a patent application is mandatory.

While the US law does give significant financial discounts to small and medium size enterprises who are seeking a patent, there is still a barrier for these entities that may not be able to afford the application process; hence, protecting one's idea from public disclosure is of increasing significance. These issues are not reserved for US corporations or innovators, but in fact, the new US patent law was generated to more appropriately reflect patenting laws in the rest of the developed countries. Thus, 
innovators should be aware of these issues, including those associate with the decision to pursue a patent in multiple nation-states.

Corporate leaders in the innovation space idealize an eventual environment where users are always reached where they 'live', e.g. social networks, mobile phones, email, etc., with the ideation processing occurring behind the scenes. Keeping these processes behind the scenes may allow for more intellectual property protection, whereas displaying all ideas for the world to see may lend itself to trolls who are looking for great ideas and can thusly seek patent protection without having incurred any of the expense associated with collecting the idea.

Finally, all ideas require a 'downstream' enrichment phase, whereby instead of merely relying on a ranked list of ideas, experts collaboratively vet the very best ideas, gather evidence in support of its development and perform a variety of analyses to determine a go/no-go strategy, such as conducting a SWOT analysis (with a quantitative measures) and a feasibility study on the final and only very best ideas before they go into pre-production. Such efforts would require an assessment of the cost benefits, the strategic fit, market potential and size, and the expected return on investment, etc., in order to make certain an idea is commercially viable. While much research has been done to further explicate the best practices in this field, new and meaningful approached, methods, and metrics are continually demanded by the ever developing field of open innovation.

\section{In Place of Conclusion}

Instead of writing a standard, scholar-style chapter conclusion, let's use a gardening metaphor that summarizes the best practice. We'll plant seeds, we'll nurture the ideas that grow and eventually we will harvest them. The beforementioned challenges and future trends are expected to make new paths along these roads.

The first step would be Seeding. This is the process of issuing Challenges or Campaigns. Without this type of focus; if we just open up a "general idea box", we're likely to capture only incremental innovation, or worse, ideas that are truly not useful to anyone. The challenges or seeds are issued. "Please help us and give us your ideas on this topic." We need to reach potential users where they live electronically. Perhaps an email or a twitter feed or a Facebook page has the challenge issued. To make it easy a link or URL is included to take the potential user precisely where the collaborative conversation is taking place.

Contributions must be acknowledged: "Thank you for your idea", "Your idea has received a comment", "Your idea has been merged with similar ideas", Your idea has been promoted", "Your idea is going into production". Administrators or moderators of the technology give guidance, they drive adoption and both build critical mass (for the statistical calculations of large crowds to work) and create momentum and excitement in the project. 
Vrgovic, P.; Walton, A. \& Shulkin, R.: Improving Open Innovation: Challenges for...

The next part of the process is the Feeding part of our Gardening metaphor, or the nurturing of the Collaboration process. Moderators act to inspire contributors perhaps by educating them with information on the challenge topic. The administrators moderate a discussion, which implies they know something about the subject. They forge connections between collaborators who demonstrate similar interests. To keep the process going and to keep contributors enthused, moderators need to communicate success. Besides contribution acknowledgment, this is the strongest motivator to continuing engagement.

The "heavy lifting" part of the process might be thought of as Weeding. This is where administrators encourage the flow of ideas. Moderators look for similar content in order to merge or cluster them. The "best" ideas, whether based on the most votes, or the most points or using a social science algorithm to measure social networking activity are selected and promoted. Subsequently downstream enrichment takes place next. Experts examine these best ideas, testing their premise, looking for flaws in thinking, encouraging others to provide solutions to weaknesses. The opportunity each winning idea presents typically requires a value to be assigned so it can be measured against others.

In the real world, a final review or feasibility study might come next. Before an organization spends money to put this winning idea into production, they'll want to look at every aspect of the idea to be certain it is a good financial decision. Is it cost effective? Is it realistic? Is there a market for this?

The last stage of the gardening process is to Harvest these winning ideas. This is where the administrative team executes the best idea. Here moderators select project candidates, they prepare a final assessment, put the winning ideas into production. Perhaps some of the ideas that did not make it this far are pushed back into an earlier stage of the process because they still have value. The moderators also begin to consider the next challenge or seed. Once the audience of contributors has been assembled, a new challenge can keep these people involved in the process for future endeavours.

\section{Literature}

Aiken, M., Sloan, H., Paolillo, J., \& Motiwalla, L. (1997).The use of two electronic idea generation techniques in strategy planning meetings. Journal of Busines Communication, 34(4), 370-382

Alam, I. (2003). Commercial Innovations from Consulting Engineering Firms: An Empirical Exploration of a Novel Source of New Product Ideas. Journal of Product Innovation Management, 20(4), 300-313

Balsano Nina E.Lee, Richard K.Miley, John W.Morse, Terri F.Roberts, David A., T. J. G. (2008). Identify your innovation enablers and inhibitors. Research Technology Management, 51(6), 23 
Baruah, J., \& Paulus, P. B. (2008). Effects of Training on Idea Generation in Groups. Small Group Research, 39(5), 523-541

Benkler, Y. (2006). The wealth of networks: How social production transforms markets and freedom. Yale University Press

Berthon, P. R., Pitt, L. F., McCarthy, I., \& Kates, S. M. (2007). When customers get clever: Managerial approaches to dealing with creative consumers. Business Horizons, 50(1), 39-47

Bessant, J., Lamming, R., Noke, H., \& Phillips, W. (2005). Managing innovation beyond the steady state. Technovation, 25(12), 1366-1376

Björk, J. (2012). Knowledge Domain Spanners in Ideation. Creativity and Innovation Management, 21(1), 17-27

Bogers, M., Afuah, A., \& Bastian, B. (2010). Users as Innovators: A Review, Critique, and Future Research Directions. Journal of Management, 36(4), 857-875

Bogers, M., \& West, J. (2012). Managing Distributed Innovation: Strategic Utilization of Open and User Innovation. Creativity and Innovation Management, 21(1), 61-75

Brem, A., \& Voigt, K. I. (2007). Innovation management in emerging technology ventures - the concept of an integrated idea management. International Journal of Technology, Policy and Management, 7(3), 304

Chalkiti, K., \& Sigala, M. (2008). Information sharing and idea generation in peer to peer online communities: The case of 'DIALOGOI'. Journal of Vacation Marketing, $14(2), 121-132$

Chesbrough, H. W. (2003). Open innovation: The new imperative for creating and profiting from technology. Harvard Business Press

Chiaroni, D., Chiesa, V., \& Frattini, F. (2010). Unravelling the process from Closed to Open Innovation: evidence from mature, asset-intensive industries. R\&D Management, 40(3), 222-245

Cooper, R. G. (2008). Perspective: The Stage-Gate ${ }^{\circledR}$ Idea-to-Launch ProcessUpdate, What's New, and NexGen Systems*. Journal of Product Innovation Management, 25(3), 213-232

Dahl, D. W., \& Moreau, P. (2002). The Influence and Value of Analogical Thinking During New Product Ideation. Journal of Marketing Research, 39(1), 47-60

Dahlander, L., \& Gann, D. M. (2010). How open is innovation? Research Policy, 39(6), 699-709

Daley, K. E. (2005). Taking Care of Your Creativity. The Journal of Museum Education, 30(1), 23-31

Daniels, K., Wimalasiri, V., Cheyne, A., \& Story, V. (2011). Linking the demandscontrol-support model to innovation: The moderating role of personal initiative on the generation and implementation of ideas. Journal of Occupational and Organizational Psychology, 84(3), 581-598 
Vrgovic, P.; Walton, A. \& Shulkin, R.: Improving Open Innovation: Challenges for...

Diehl, M., \& Stroebe, W. (1987). Productivity loss in brainstorming groups: Toward the solution of a riddle. Journal of Personality and Social Psychology, 53(3), 497-509 Dodds, R. A., Smith, S. M., \& Ward, T. B. (2002). The Use of Environmental Clues During Incubation. Creativity Research Journal, 14(3/4), 287-304

Gassmann, O., Enkel, E., \& Chesbrough, H. (2010). The future of open innovation. R\&D Management, 40(3), 213-221

Gassmann, O., Sandmeier, P., \& Wecht, C. H. (2006). Extreme customer innovation in the front-end: learning from a new software paradigm. International Journal of Technology Management, 33(1), 46-66

Gemmell, R. M., Boland, R. J., \& Kolb, D. a. (2012). The Socio-Cognitive Dynamics of Entrepreneurial Ideation. Entrepreneurship Theory and Practice, 36(5), 1053-1073 Girotra, K., Terwiesch, C., \& Ulrich, K. T. (2010). Idea Generation and the Quality of the Best Idea. Management Science, 56(4), 591-605

Glassman, B., \& Walton, A. (2014). Idea Evaluation and Management. In P. Gupta \& B. Trusko (Eds.), Global Innovation Science Handbook. New York: McGraw-Hill Education

Grieves, M. (2014). Practice, Process, and Innovation. In P. Gupta \& B. Trusco (Eds.), Global Innovation Science Handbook. New York: McGraw-Hill Education.

Hellmann, T., \& Perotti, E. (2011). The Circulation of Ideas in Firms and Markets. Management Science, 57(10), 1813-1826

Iyer, L. R., Doboli, S., Minai, A. a, Brown, V. R., Levine, D. S., \& Paulus, P. B. (2009). Neural dynamics of idea generation and the effects of priming. Neural networks : the official journal of the International Neural Network Society, 22(5-6), 674-86

Jung, J. H., Lee, Y., \& Karsten, R. (2011). The Moderating Effect of ExtraversionIntroversion Differences on Group Idea Generation Performance. Small Group Research, 43(1), 30-49

Karni, R., \& Shalev, S. (2004). Fostering innovation in conceptual product design through ideation. Information Knowledge Systems Management, 4, 15-33

Knoll, S. W., \& Horton, G. (2011). Changing the Perspective: Using a Cognitive Model to Improve thinkLets for Ideation. Journal of Management Information Systems, 28(1), 85-114

Kusiak, A. (2009). Innovation: A data-driven approach. International Journal of Production Economics, 122(1), 440-448

Leggett Dugosh, K., Paulus, P. B., Roland, E. J., \& Yang, H.-C.(2000). Cognitive stimulation in brainstorming. Journal of Personality and Social Psychology, 79(5), 722-735

Liikkanen, L. a., \& Perttula, M. (2010). Inspiring design idea generation: insights from a memory-search perspective. Journal of Engineering Design, 21(5), 545-560. 
Lilien, G. L., Morrison, P. D., Searls, K., Sonnack, M., \& Hippel, E. von.(2002). Performance Assessment of the Lead User Idea-Generation Process for New Product Development. Management Science, 48(8), 1042-1059

MacCrimmon, K. R., \& Wagner, C. (1994). Stimulating Ideas Through Creativity Software. Management Science, 40(11), 1514-1532

Magnusson, P. R. (2009). Exploring the Contributions of Involving Ordinary Users in Ideation of Technology-Based Services. Journal of Product Innovation Management, 26(5), 578-593

Marakas, G. M., \& Elam, J. J. (1997). Creativity Enhancement in Problem Solving: Through Software or Process? Management Science, 43(8), 1136-1146

Mendonca, R., Povoa, A., \& Oliveira, P. (2012). The Antecedents of Idea Management Capability: Empirical Investigation of Idea Management Systems. Available at SSRN 2030859

Misawa, N., \& Fujita, M. (2009). A Proposal of XB-Method, an Idea Generation System for New Services Using User Experiences. In M. Kurosu (Ed.), Human Centered Design SE - 32 (Vol. 5619, pp. 276-283). Springer Berlin Heidelberg Murray, F., \& O'Mahony, S. (2007). Exploring the Foundations of Cumulative Innovation: Implications for Organization Science. Organization Science, 18(6), 1006-1021

Nelson, B. a., Wilson, J. O., Rosen, D., \& Yen, J. (2009). Refined metrics for measuring ideation effectiveness. Design Studies, 30(6), 737-743

Nijstad, B. A., Stroebe, W., \& Lodewijkx, H. F. M. (2002). Cognitive stimulation and interference in groups: Exposure effects in an idea generation task. Journal of Experimental Social Psychology, 38(6), 535-544

Obschonka, M., Silbereisen, R. K., \& Schmitt-Rodermund, E. (2012). Explaining Entrepreneurial Behavior: Dispositional Personality Traits , Growth of Personal Entrepreneurial Resources, and Business Idea Generation. The Career Development Quarterly June, 60(June), 178-191

Piller, F. T., \& Walcher, D. (2006). Toolkits for idea competitions: a novel method to integrate users in new product development. R\&D management, 36(3), 307-318.

Rangaswamy, A., \& Lilien, G. L. (1997). Software Tools for New Product Development. Journal of Marketing Research, 34(1), 177-184

Rietzschel, E. F., Nijstad, B. a., \& Stroebe, W. (2006). Productivity is not enough: A comparison of interactive and nominal brainstorming groups on idea generation and selection. Journal of Experimental Social Psychology, 42(2), 244-251

Sandström, C., \& Björk, J. (2010).Idea management systems for a changing innovation landscape. International Journal of Product Development, 11(3), 310-324. Schulze, T., Indulska, M., Geiger, D., \& Korthaus, A. (2012). Idea assessment in open innovation: A state of practice, In 20th European Conference on Information Systems (ECIS) 2012 Proceedings (Vol. 149, p. 149). Association for Information Systems 
Vrgovic, P.; Walton, A. \& Shulkin, R.: Improving Open Innovation: Challenges for...

Shah, J. J., Smith, S. M., \& Vargas-Hernandez, N. (2003). Metrics for measuring ideation effectiveness. Design Studies, 24(2), 111-134

Sosa, M. E. (2011). Where Do Creative Interactions Come From? The Role of Tie Content and Social Networks. Organization Science, 22(1), 1-21

Sowrey, T. (1990). Idea Generation: Identifying the Most Useful Techniques. European Journal of Marketing, 24(5), 20-29

Stevens, G. A., \& Burley, J. (1997). 3,000 raw ideas = 1 commercial success! Research Technology Management, 40(3), 16

Thom, N., \& Etienne, M. (2000). Effizientes Innovationsmanagement: Grundvoraussetzungen in der Unternehmensführung und im Personalmanagement. Zeitschrift für Ideen-management, 1, 4-11

Toubia, O. (2006). Idea Generation, Creativity, and Incentives.Marketing Science, 25(5), 411-425

Toubia, O., \& Florès, L. (2007).Adaptive Idea Screening Using Consumers.Marketing Science, 26(3), 342-360

Ulwick, A. W. (2002). Turn customer input into innovation. Harvard business review, 80(1), 91-7, 126

Verhaegen, P.-A., Peeters, J., Vandevenne, D., Dewulf, S., \& Duflou, J. R. (2011). Effectiveness of the PAnDA ideation tool. Procedia Engineering, 9, 63-76

Von Hippel, E. (1978). Successful Industrial Products from Customer Ideas. Journal of Marketing, 42(1), 39-49

Von Hippel, E. (2007). Horizontal innovation networks - by and for users. Industrial and Corporate Change, 16(2), 293-315

Walton, A. L., Tomovic, C. L., \& Grieves, M. W. (2013). Product Lifecycle Management: Measuring what is Important - Product Lifecycle Implementation Maturity Model. 10th International Conference on Product Lifecycle Management. Nantes

West, J., \& Bogers, M. (2011).Profiting from External Innovation: A Review of Research on Open Innovation. 9th International Open and User Innovation Workshop (pp. 1-46). Vienna

West, J., \& Gallagher, S. (2006). Challenges of open innovation: the paradox of firm investment in open-source software. R\&D Management, 36(3), 319-331

West, J., \& Lakhani, K. R. (2008).Getting clear about communities in open innovation. Industry and Innovation, 15(2), 223-231

West, J., \& O'mahony, S. (2008). The Role of Participation Architecture in Growing Sponsored Open Source Communities. Industry and Innovation, 15(2), 145-168 